\title{
How COVID-19 impacts the U.S. economy and predictions about the future.
}

\author{
Fangze $\operatorname{Tian}^{1}$ \\ ${ }^{1}$ Buckingham Browne and Nichols Upper School
}

\begin{abstract}
The spread of COVID-19 is one of the most impactful global events in recent years. It has destroyed the U.S. economy and financial market. In just several months, the stock market experienced major fluctuations, the entire economy has basically stopped, and the unemployment rate peaked. Its severity even penetrated people's daily lives; many are not getting basic requirements needed for survival. As cases increase daily, more and more are concerned with how the future will look like and what this pandemic will do to the economy in the long run. Faced with many uncertainties in macroeconomic trends and the continuous spreading of the virus, I have compared this current crisis with the subprime mortgage crisis in 2008. With a goal to reasonably forecast future developments of the U.S. economy, from both micro and macro perspectives, financial market trends and government actions have been analyzed. Specifically, the two events' causes, essences, policies' effectiveness, and other factors have been evaluated and suggestions in adjusting government policies have also been made. Unlike the 2008 crisis, this crisis will require longer, more complex, and more flexible processes and regulations to recover, and citizens should be prepared for this slow recovery. But overall, a promising outlook for the U.S. economy still stands in the long-run.
\end{abstract}

\section{Introduction}

For the past ten years, the U.S. economy has been in one of its best conditions, experiencing continuous positive growths and trends. But recently, the COVID-19 pandemic has greatly and negatively impacted the world's economy, causing it to worsen faster than ever. According to the World Bank, the global GDP will shrink by $5.2 \%$ in 2020 . Contraction will occur with the U.S. economy by $6.1 \%$ and Europe by $9.1 \%$ in 2020 . As shown in Graph 1, the second-quarter GDP in the U.S. decreased by $32.9 \%$. In addition, for the first time in history, multiple circuit breakers were triggered and major fluctuations occurred in the U.S. stock market. Trade between the U.S. and its partners have also been put on a halt.

Graph 1: GDP Growth Rate (quarter \%) in the U.S.

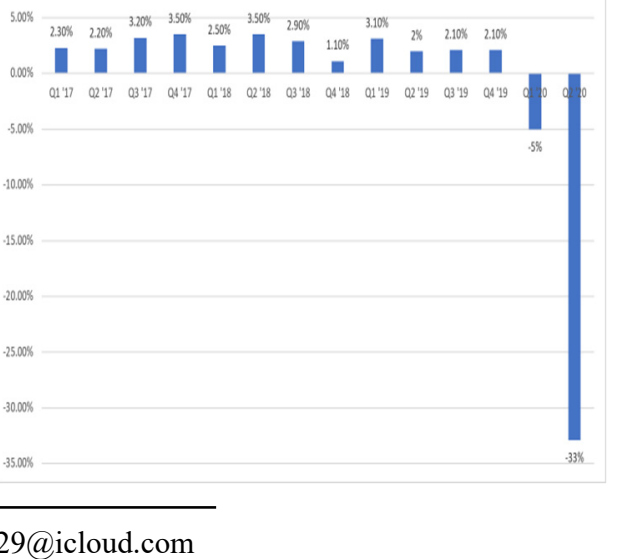

Specification: On July 30, 2020, the U.S. Bureau of Economic Analysis released the Real GDP for Quarter 2 of 2020. The Real GDP sharply decreased at an annual rate of $32.9 \%$ in Quarter 2, breaking the record since 1947.

Not only is the financial market greatly harmed, the daily lives of citizens are greatly affected as well. People are risking their health every time they leave their residences. Plans made, whether for education, traveling, or any other purposes, all had to be changed or canceled. As shown in Graph 2, the unemployment rate rose from $3.5 \%$ in February to $14.7 \%$ in April 2020. And according to Columbia University economics professor Dr. Brendan O'Flaherty, the number of homeless people in the U.S. will increase by $40-45 \%$; as shown in Graph 3, this means homelessness in the U.S. would reach the highest it has ever been at for the past 13 years. Many even lack basic necessities such as food and shelter that are crucial for survival. The tension and stress only increase more and more as the days continue. Noone's life is anywhere close to normal, and everyone is anxious and worried about their future. Will the U.S. economy recover? 
Graph 2: Monthly Unemployment Rate in the U.S. from June 2019 to May 2020 (seasonally-adjusted)

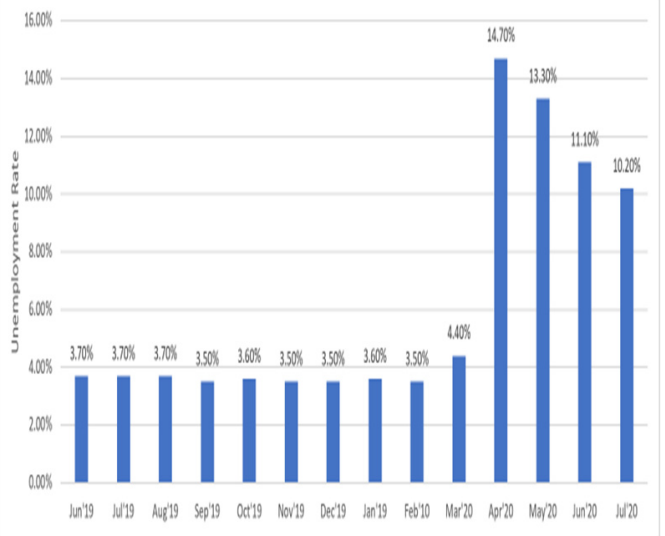

Specification: According to the U.S. Bureau of Labor Statistics, the unemployment rate in the U.S. in April 2020 broke the monthly high record of $14.7 \%$ since the Great Depression.

Graph 3: Homelessness in the U.S.

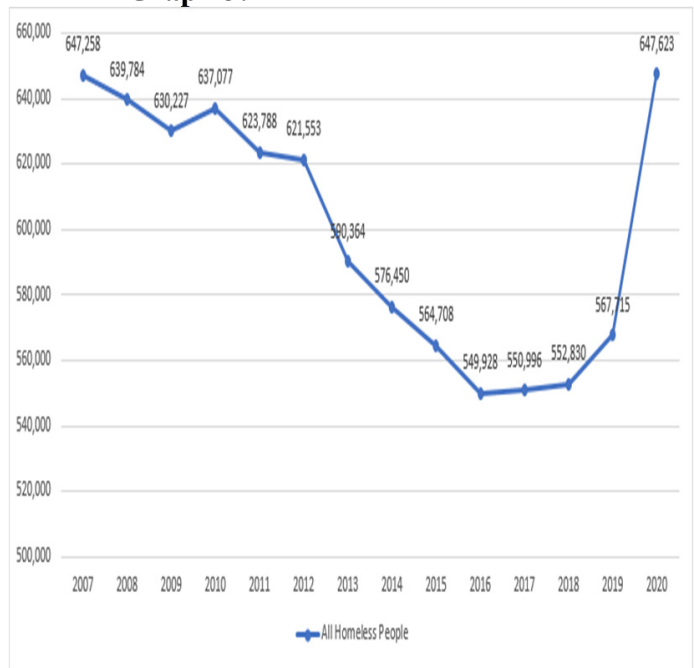

Specification: According to the U.S. Department of Housing and Urban Development, in just three months of 2020, the number of homeless people in the U.S. increased by nearly 100,000 , setting the record for the past 13 years.

Back in 2008, we faced a financial crisis that also resulted in fluctuations in the stock market and economic contractions. But the economy was able to quickly recover and even improve afterward. So will the U.S. economy this time be able to recover as quickly and well as it did in 2008? The answers to these questions are what people are seeking as uncertainties and stress quickly build up; they are desperate to know when their lives will return to normal again.

In hopes to answer these questions and predict the future of the U.S. economy, this study compares the 2008 crisis with 2020 by analyzing the underlying causes, the policies, and values of important economic indicators.

In 2008, only the financial market was affected and technological breakthroughs soon occurred in the following years. However, this time in 2020, the entire U.S. economy has completely stopped and there have been no technological breakthroughs yet. And thus, in the short run, it is unlikely that the U.S. economy would be able to recover as quickly as it did in 2008. But in the long run, there is still a positive outlook because the factors that support long term growth in the U.S. are still in effect; some of these factors include domestic consumption, possible new investment growth, and possible technological breakthroughs.

\section{Analysis}

To better understand the 2020 crisis and predict the aftermath of this crisis, the 2020 crisis was compared and contrasted with the 2008 financial crisis.

\subsection{Similarities:}

The main similarity between the crises is that, from the asset price perspective, both experienced growth prior to the crises. Growth in 2008 was in real estate prices while 2020 's growth was in stock prices. Before the 2008 financial crisis, home prices continuously increased. As shown below in Graph 4, the S\&P/Case-Shiller U.S. National Home Price Index increased by $121.25 \%$ from 83.44 in July 1996 to 184.61 in July, 2006; the housing market was doing exceptionally well. On top of the rapidly rising housing prices, the amount of subprime mortgages also grew quickly from $8.3 \%$ of all mortgages in 2003 to $23.5 \%$ in 2006; $\$ 600$ billion worth of subprime mortgages were issued in 2006. These caused the housing market to be overheated, forming the real estate bubble, and ultimately started the 2008 financial crisis. Similarly, before the 2020 crisis during the 2010 s, the U.S. stock market was also a bull market before the market crashed. As shown in Graph 5, DJIA grew by $357 \%$ and NASDAQ grew by $677 \%$. Both crises had a booming economy leading up to the crisis.

Graph 4: S\&P/Case-Shiller U.S. National Home Price Index

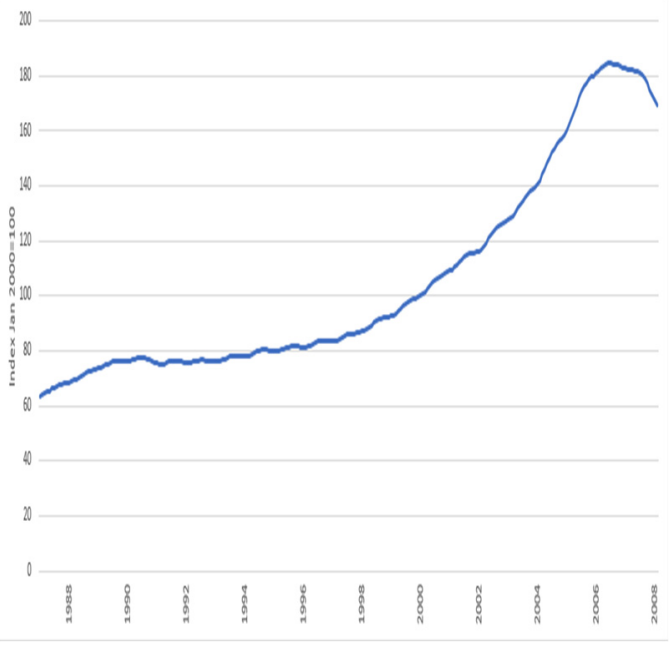

Specification: Home prices before 2008 rapidly went up, forming a real estate bubble, leading to the 2008 financial crisis, as stated by the Federal Reserve Bank of St. Louis. 
Graph 5: Stock prices of NASDAQ Composite Index (IXIC), Dow Jones Industrial Average Index (DJI), and S\&P 500 Index (GSPC) before 2020

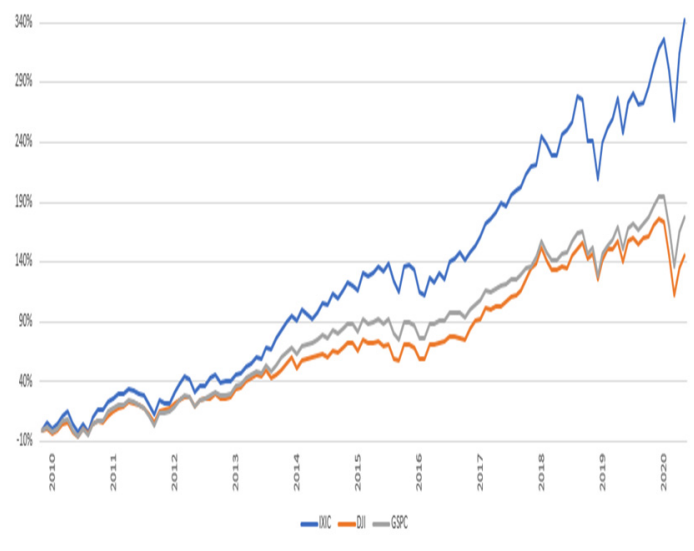

Specification: Similar to the home prices before the 2008 crisis, various U.S. stock indexes grew consistently and dramatically before 2020 .

\subsection{Essence:}

Many differences exist between the crises. To start, the essence and scope affected by the two events are different. 2008 was a crisis on Wall Street, whereas 2020 was a crisis for the entire population and society. The 2008 financial crisis started with the subprime mortgage crisis that led to the bursting of the real estate bubble, which caused more mortgages to default and also rapidly increased real estate toxic loans. This resulted in many financial institutions going bankrupt and shutting down. This chain reaction ultimately caused the financial market to lose liquidity and a recession soon followed. But only the financial market was affected, not the actual economy; demand did not change and suppliers continued to produce. Differently in 2020, COVID-19 is affecting the entire world and all its people; both economic and social affairs stopped and global trading decreased. In addition, with the rapid decrease in oil prices, the world's economy began to fall apart. There was only demand for basic survival necessities; no one was going outside or traveling anymore. This in turn caused an increase in the unemployment rate, which indicates that the citizens are impacted as well. Following the 2008 crisis, the highest level of unemployment reached was 15.3 million Americans, whereas this time 26.5 million Americans are already jobless and the number still continues to increase.

\subsection{Stock market:}

While the essence of the crises is different, to better understand the development process and extent of the two crises, I examined the financial market, specifically the motions of the stock market; measures and trends in the stock market are crucial economic indicators. During the 2008 financial crisis, the stock market experienced major setbacks. Illustrated in Graph 6 below, from October 11th, 2007 to March 6th, 2009, the Dow fell by
7,500 points from 14,198 to 6,470 , decreasing by $54.43 \%$ Then over the next ten years after the 2008 financial crisis, the stock market grew due to the fourth industrial revolution and internet companies launching their IPOs. On February 12th, 2020, DJIA reached its highest in 10 years, 29,569. But then Covid-19 hit, and DJIA quickly decreased by $38.40 \%$ by March 23th, as reflected in Graph 7. Comparing changes in the stock market in 2008 and 2020 from the time span perspective, the financial crisis in 2008 had a bigger decrease overall, but that entire decrease happened over seventeen months. This was because the chain reaction which started from the overheated housing market occurred step-by-step to impact the financial market. Thus the drop was gradual. On the other hand, the whopping $38.4 \%$ decrease in 2020 occurred all within one and a half months. And since the decrease in 2008 was gradual, the short-term impact on investors was not as massive as 2020 .

Graph 6: Stock prices of NASDAQ Composite Index (IXIC), Dow Jones Industrial Average Index (DJI), and S\&P 500 Index (GSPC) during the 2008 Financial Crisis

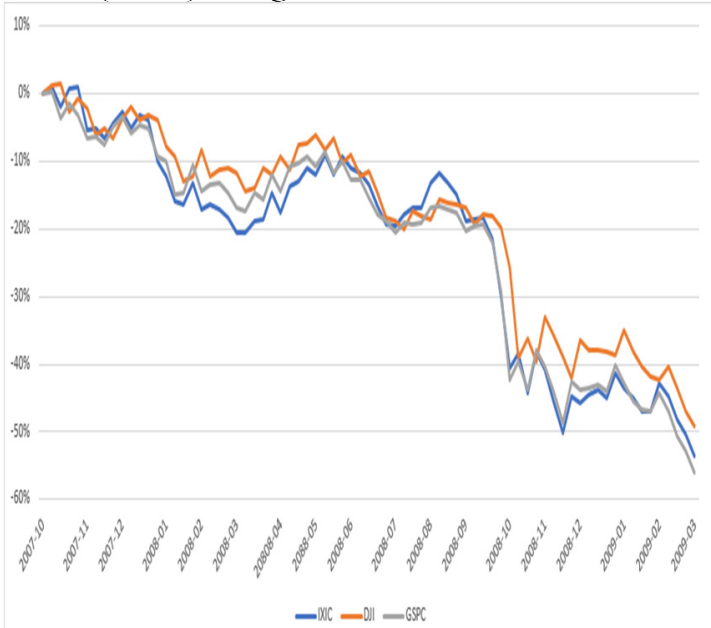

Specification: During the 2008 financial crisis, the U.S stock prices took seventeen months to complete its decrease. The overall trend was placid and gentle, except for the only drop during the fall of 2008.

Graph 7: Stock prices of NASDAQ Composite Index (IXIC), Dow Jones Industrial Average Index (DJI), and S\&P 500 Index (GSPC) in 2020

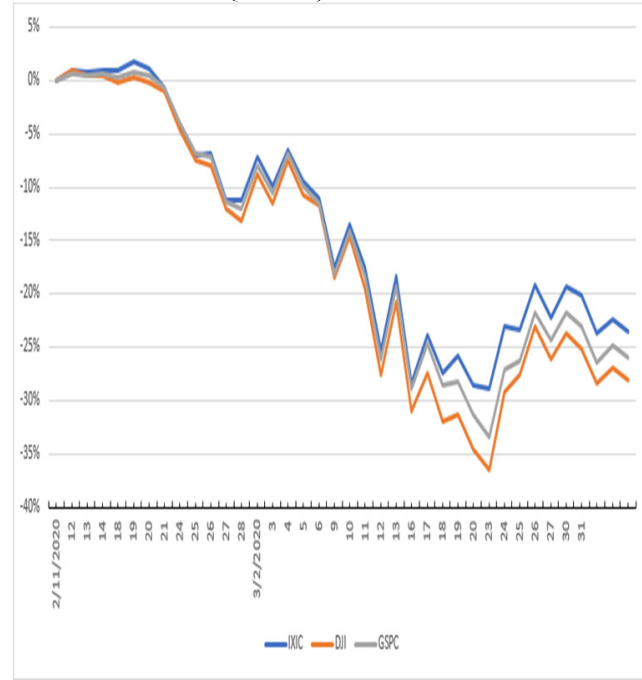


Specification: In contrast to 2008, the decrease in stock prices in the 2020 crisis only took 24 trading days. Sharp decreases are seen during the four circuit breakers: March 8th, 12th, 16th, and 18th.

In addition to a comparison of the two crashes via the timespan perspective, by comparing the two crashes in terms of intensity and severity, it can also be concluded that the crisis in 2020 resulted in a greater meltdown in the stock market. As indicated in Graph 7 above, S\&P 500 decreased by $35.42 \%$ from February 19th to March 23rd: from 3394 to 2192. On top of that, four circuit breakers occurred respectively on March 8th, 12th, 16th, and 18th. A circuit breaker, which was put into place after Black Monday in 1987, temporarily halts trading when S\&P 500 drops by 3 levels of 7\%, 13\%, and 20\%. The goal of a circuit breaker is to prevent panic selling that would lead to crashes in the stock market; the halt gives traders time to think through transactions. During each of the four circuit breakers, the S\&P 500 index decreased by $8.01 \%, 9.59 \%, 12.17 \%$, and $9.8 \%$ respectively. Only five circuit breakers have ever occurred in history, and four of those occurred within ten days. The continuously plunging stocks in March show the severity and speed of the 2020 crisis; during the 2008 financial crisis, there were no circuit breakers. The reasons for the four back-to-back circuit breakers are the huge rise from the past decade, the oil price crash, and COVID-19. As pointed out earlier in Graph 5, for the past decade, the stock market has been in a bull market and was the longest-running one in history. DJIA grew by $357 \%$ to 29,569 on February 12th, 2020; NASDAQ grew even more by $677 \%$ to 9838 on February 19th, 2020. This long-term bull market of growing stock prices is primarily a result of the internet, other technological breakthroughs, and stability of the economy. As a result, countless investors have acquired huge amounts of unrealized profits, causing the stock market to accumulate strong demand. From the macro-perspective, the Fed and the U.S. Treasury also used monetary and fiscal policies, such as quantitative easing and lowering of interest rates, to stimulate the economy when stock price fluctuated. Through both micro and macro measures, the stock market is able to remain as a bull market for the past decade. Furthermore, the world is also experiencing modern history's most serious pandemic, COVID-19. COVID-19's wide range of effects on the economy, on the people, and many more aspects have never been seen before. The virus quickly caused global production, trade, and social activities to stop; this increased the speed and severity of the crash in the stock market. The Fed continued trying to stimulate the stock market through its policies to lower interest rates and increase the money supply; some results were positive. The stock market recovered, and NASDAQ also peaked, but how are the actual economy and corporations' profit doing?

\subsection{Government actions:}

Not only did the stock market activities and trends differ during the two crises, but the government also used different policies to help the financial market to recover.

During the 2008 financial crisis, the rising amount of defaults in subprime mortgages caused a chain reaction of bankruptcy among major financial institutions with high leverage rates; those remaining were also afraid of giving out loans. This decreased the liquidity in the financial market. From the macro perspective, in order to increase liquidity in the market, the Fed announced rounds of quantitative easing, where it bought long-term government and corporate bonds to lower long-term interest rates, even though it was already close to zero. The first round was announced on November 25th, 2008, where the Fed purchased $\$ 600$ billion in mortgage-backed securities and long-term Treasury bonds. The Fed's portfolio reached $\$ 2.1$ trillion by June 2010 after the Fed continued to purchase more long-term government bonds and other financial assets. Three more rounds of quantitative easing occurred, with the Fed buying $\$ 600$ million Treasury securities in the second round, $\$ 40$ billion each month in the third round, and the $\$ 85$ billion each month in the fourth round. These rounds increased the money supply and liquidity. There were more lending and spending activities that then helped cover banks' toxic subprime mortgages which ultimately sped up and boosted the economy. The housing market improved too because mortgage rates lowered. Dollar values lowered and interest rates lowered, increasing foreign demand for U.S. goods since exports were cheaper; this created more sales and jobs for U.S. companies. Overall, quantitative easing allowed economic growth while the core Consumer Price Index remained lower than the Fed's target $2 \%$, meaning that huge inflation did not occur. Moreover, the fourth industrial revolution of the internet also brought the rise of major companies such as Amazon, Google, and Facebook. With the opening of these companies came many new job openings; the unemployment rate decreased. Then the rise of internet finance allowed peer-to-peer lending and crowdfunding which lowered the unemployment rate even more. These all contributed to the fast recovery in 2008. From a micro perspective, the government directly interfered to invest in financial corporations. For instance, Fannie Mae and Freddie Mac were bailed out and were put in conservatorship by the Federal Housing Finance Agencies on September 6th, 2008 after huge losses in their portfolios since 2007; the two companies received $\$ 187$ billion worth of bailout funding. This stabilized the housing market because further subprime mortgage losses were prevented. Since then, Fannie Mae and Freddie Mac have repaid more than $\$ 300$ billion to the U.S. Treasury. The U.S. government rescued major financial institutions in order to protect the overall economy.

The government's priorities were also different in 2008 and 2020. In 2008, its primary goal was to help the financial market recover. But in 2020, the government's most important focus at-hand is to overcome the virus and to ensure basic living qualities of its people and local 
businesses. The Fed quickly launched a series of bills and measures to achieve the previously described goals. The major bill passed in 2020 is the Coronavirus Aid, Relief, and Economic Security Act (CARES Act), which President Trump signed into law on March 27th, 2020. The bill is aimed to protect the people and businesses impacted by COVID-19. Individual adults who pay taxes receive a one-time deposit of up to $\$ 1,200$ with an additional $\$ 500$ per child. Through the end of July, workers affected also received an additional unemployment compensation of $\$ 600$ per week. $\$ 150$ billion are allocated for health care services like hospitals and medical centers, vaccine developments, supply chain, and protection for health care workers.

Among the many bills of the CARES Act, one to notice in particular is the Paycheck Protection Program (PPP). PPP appropriated $\$ 349$ billion at first and then increased it to $\$ 669$ billion for small businesses with less than 500 workers; the businesses could receive up to 8 weeks of financial guidance of up to $\$ 10$ million in total. This allows businesses to continue employing workers and afford rents, utilities, and other payments in order for the business to keep running. Besides taking these general steps, the Fed also introduced policies aimed to protect specific industries. Those major businesses impacted heavily by the pandemic also could receive fundings. For example, passenger airlines received \$25 billion. Furthermore, tax deadlines were also extended to July 15th, allowing people more time to cover their payments without having to deal with late filing penalties. These measures have never been taken before during the 2008 crisis.

To sum up, the government proposed many policies and passed many bills during these two crises, and while there are similarities, the differences show that 2020 will take longer to recover. For the similarity, the government exercised its power and passed policies and bills to boost the economy both times. For 2008, the primary focus was the financial market; the Fed took steps to stimulate economic activities and increase liquidity in the market. Whereas in 2020, the primary focus of the Fed is completely different; policies were aimed at helping the citizens and businesses; only when the people have met their basic needs, the economy that has stopped will then be able to be restimulated. The people affected the most by the pandemic are generally those of lower-income with little savings and the businesses affected the most are local and smaller or mid-sized businesses. The government needs to ensure that these people are getting enough money for maintaining survival necessities and that the businesses do not shut down so unemployment rate would not rise. Being able to make sure all the people are retaining basic living needs and are employed is prioritized. And after that is taken care of, the government would then need to restart the overall economy.

The initiatives stated above resulted in favorable outcomes for the U.S. in the earlier stages. For example, the one-time deposit to all residents and subsidies for small and medium-sized enterprises have increased the country's and its people's ability to combat the crisis. However, there are still flaws in the system that can be improved. First of all, measures taken by the Fed to increase the money supply and market liquidity were too aggressive. In the absence of a clear turning point in the spread of COVID-19, much of the United States is still under shutdown and the macroeconomy remains in a slowed-down state. The choice to inject large amounts of liquidity at this time into the financial market would not result in funds flowing into the actual economy, but rather flowing into the stock market in large amounts. In fact, there has not been sufficient profitable growth to support the substantial rise in the stock market since the end of March 2020. Sharp rises in the stock market due to excess liquidity would increase systemic risk in the market. Secondly, protection policies implemented by the government, like the Paycheck Protection Program, may not be as effective as expected. High unemployment benefits caused many people to receive more during the epidemic than they would normally have earned from their previous jobs.

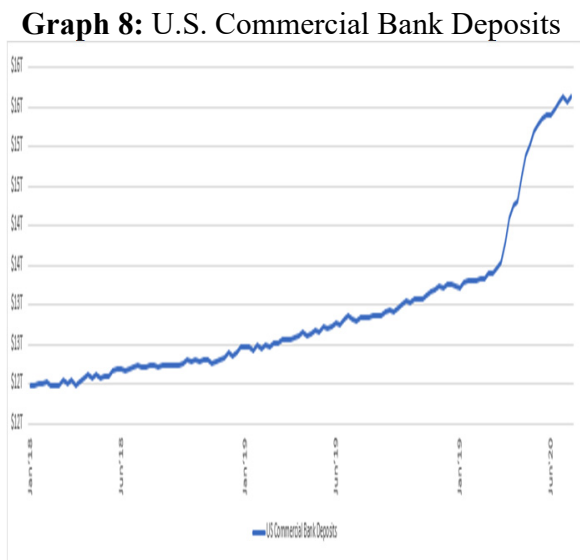

Specification: Since the Fed increased the money supply and the government passed the CARES Act, commercial bank deposits increased dramatically as well. This is another indicator of excessive liquidity, short term wise.

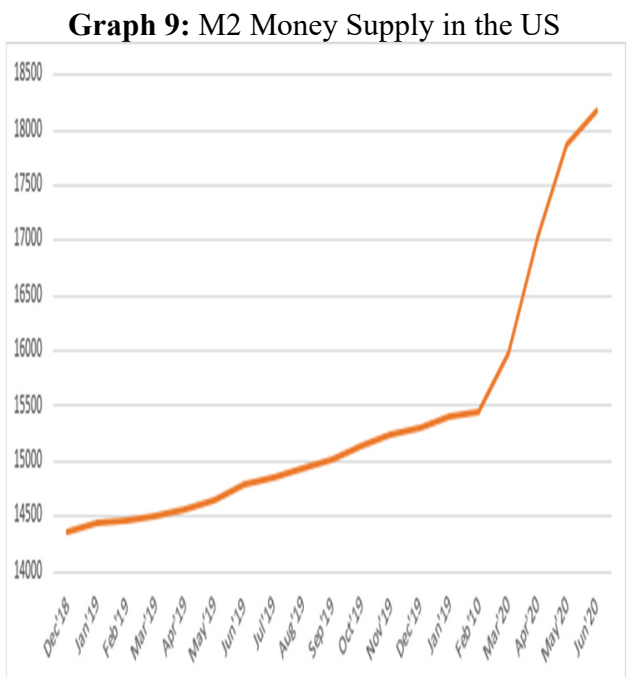

Specification: Before COVID-19, the M2 money supply has been increasing slowly and steadily. Since the 
CARES Act was passed in March, the Fed has been increasing the money supply significantly and quickly.

Based on Graph 8 from above, bank deposits have actually risen significantly during the epidemic. This means that the PPP plan was not as effective as it was expected to be. As reflected in Graph 9 above, the Fed used expansionary monetary policy, as usual, to stimulate the economy. The goal of giving out money to businesses is for businesses to invest so employees would be able to keep their job and have money to consume. But given that this crisis is different than any crisis before due to the many uncertainties, companies are afraid to invest and citizens are hesitant in consuming more. Yet, only through companies' investment and people's consumption will demand be created and the economy be restimulated. In short, most of this money put into banks means only numbers and would not have real impacts on the economy.

Additionally, a significant portion of PPP's $\$ 600$ billion went into the stock market. Many young investors like Robinhood traders have invested in the stock market; the number of Robinhood's accounts, since the end of 2019 , increased by $3,000,000$ to $13,000,000$ in May 2020 . As illustrated in Graph 10 below, the brokerage accounts of Charles Schwab, one of America's largest financial firm in securities and asset management, also increased tremendously from 12 million during the end of 2019 to 12.9 million in April 2020, 14 million in May 2020, and then 14.1 million in June 2020; these increases occurred after the CARES Act was signed into law in late March. And thus it can be predicted that when a new act aimed at improving citizens' living conditions is signed into law, the total amount of accounts would increase again. This again shows inefficiencies of the CARES Act: money should be going out to workers to consume, not be put into the financial market or institutions. In light of the above analysis, the current macroeconomic policies and measures adopted by the government still need to be adjusted in terms of timing and the specific focuses and target groups. Instead of a one-time deposit from the government, it should consider a long-term, continuous, and flexible policy to help small businesses, deciding the amount to give out based on real-time performance and needs specific to individual businesses.

Graph 10: The Charles Schwab Corporation's Active Brokerage Accounts

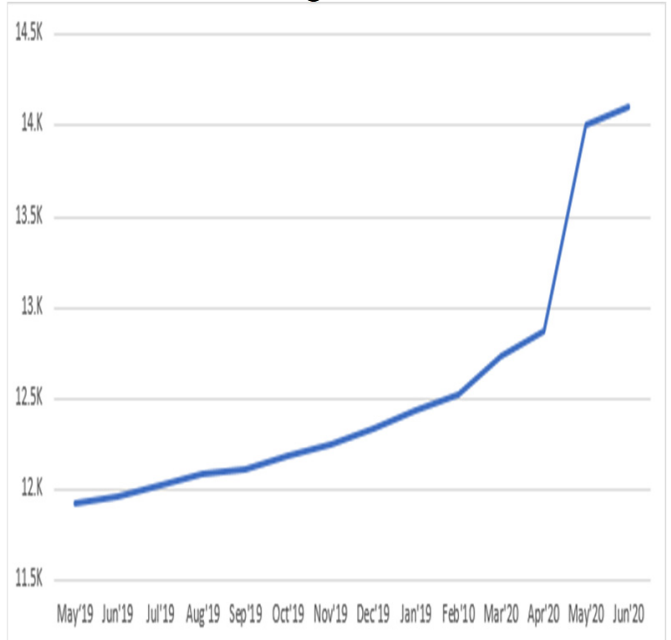

Specification: The increase in accounts in the security company after the Fed increased the money supply indicates that a significant portion of that money went into the stock market, rather than creating real demands.

\section{Outlook}

Using the similarities and differences of the 2008 financial crisis with those of the 2020 crisis, the future and the aftermath of 2020's pandemic can be predicted.

Graph 11: Number of New Cases in the U.S. (thousands):

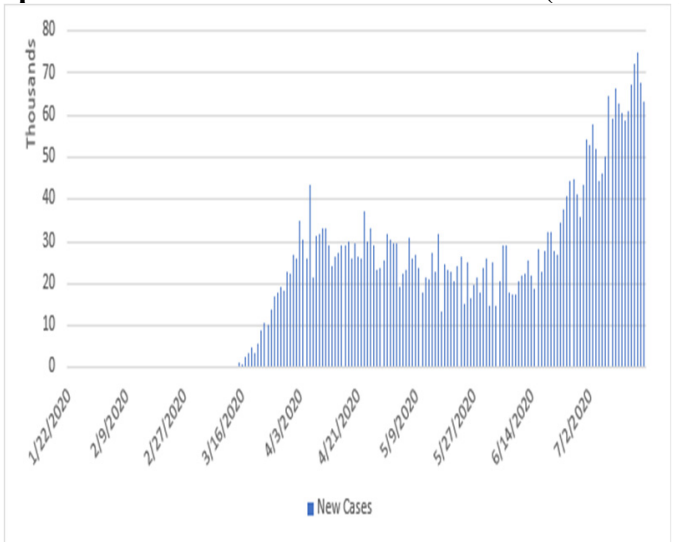

Specification: New cases daily continue to increase after a brief period of decreasing new cases in May, as according to the U.S. Center for Disease Control and Prevention

As more and more businesses and corporations began to reopen, the number of cases started increasing again. As indicated in Graph 11, the number of new cases quickly shot up in the U.S. On July 16th, more than 77,000 new confirmed cases were recorded in the U.S. This is primarily due to many states beginning to reopen in May and June. Reopening has helped lower the unemployment rate by $4.5 \%$, from April's $14.7 \%$ to July's $10.20 \%$, as demonstrated in Graph 12 below. But due to the increase in cases, many states have readopted stricter regulations. Thus, it can be predicted that Quarter 3's GDP and unemployment rate for the U.S. will not significantly improve from Quarter 2's. This also means that the impact of the virus on the economy is long-term and the economy is still far from full recovery. The recovery of the economy will repeatedly alter between stages as COVID-19's development changes; it would not be a direct and fast process. Political competition between countries will become more frequent; tension will especially increase between major political powers. But amidst the uncertainties, predictions can still be made about the future. 
Graph 12: Monthly Unemployment Rate in the U.S. from March 2019 to July 2020 (seasonally-adjusted)

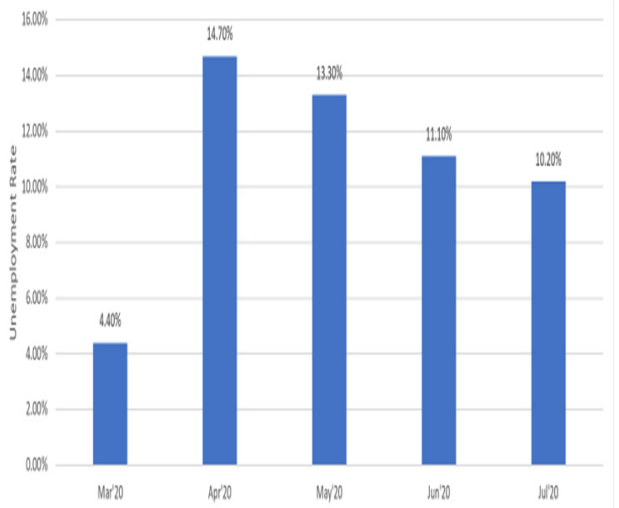

Specification: According to the U.S. Bureau of Labor Statistics, the unemployment rate in the U.S., since it broke the monthly record in April 2020, has shown constant decrease in the following months.

Graph 13: GDP Growth Rate (annual \%)

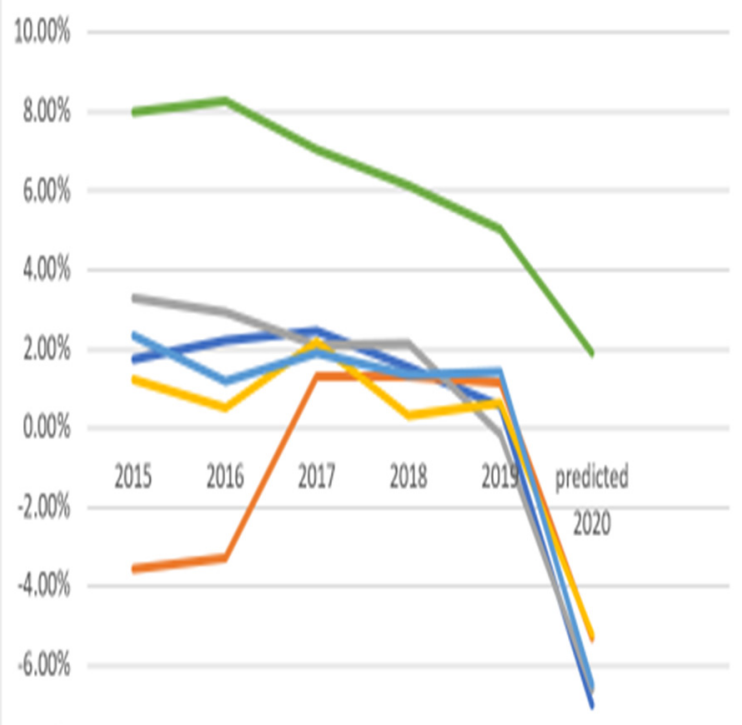

$.800 \%$

$$
\text { -Germany -Brazl -Mexico - Japan } \longrightarrow U K=\text { India }
$$

Specification: The annual GDP in the past five years, based on the World Bank, in Germany, Brazil, Mexico, Japan, the UK, and India are illustrated. In addition, the predicted 2020 GDP according to the International Monetary Fund (IMF) are also shown.

First is an outlook of future trends from a global perspective. Graph 13 shows the IMF's World Economic Outlook (2020) done in April. And already, most major countries' GDP were expected to plummet significantly. Different countries are also impacted at different degrees by COVID-19; some were able to retain it better than others, but most have experienced intense impacts. According to Graph 13 above, most countries' GDP are expected to fall by more than 5\%. Since COVID-19 worsened after April, it can be expected that the actual decrease would be bigger than the prediction. This shows that the crisis we are facing now is causing a global contraction, not just nation-wide. For the global economy to improve, countries must all improve. Any individual country's poor state will result in a chain reaction that hinders collective global growth.

These issues that arose in the global economy have also created troubles in the society and for the people. From the global perspective, conflicts between countries began to surface. These disputes would cause globalization to fall backward. And even when the virus ceases, global trade and political and economic structures will go through major changes; globalization will fall backward as well. As different countries are affected by the virus to different degrees of severity, the U.S. would need to bring back its industries and companies that used to produce outside the country, especially those critical to economic security and health of the people and the country. For example, production for medical equipment and other protective and basic gears like face masks must be brought back to its own land to ensure that the country has a steady stream of supplies so that citizens are safe. In the short run, this would increase investment significantly and also net export in the country, which would increase the GDP. However, since the entire economy had shut down upon the appearance of COVID-19, the U.S. needs to restart the economy in some way. In such a complex and ever-changing world, how should the U.S. balance its own interests while continuing to maintain its global influence and leadership? The U.S. has already lost the head start to lead the world out of this virus, but it can still make significant contributions. The U.S. has the world's most powerful scientific and technological innovation, the most developed bioengineering technologies, and the most advanced medical research and development institutions. So, the U.S. should mobilize these resources for the development of a vaccine for COVID-19; the U.S. should then create a large-scale production plan of the products it developed. The U.S. should strive to take the lead in using vaccines and drugs to eradicate the virus and lead the world to win the battle against COVID-19. If this vision is realized, it will be a great opportunity for the U.S. to consolidate and strengthen its position in the world against the backdrop of globalization and the struggles among political forces.

In addition to the political and international relations aspects, new technological advancements and new demands also need to happen. On a positive note, there already have been some advancements: the internet tech revolution that started after the 2008 financial crisis has continued until present day. So there is an increase in demand for online services. Reflected in Graph 13 below, on February 18th, 2020 NASDAQ index reached 9838, dropped to its lowest of 6631, but it began recovering on March 23rd and reached 10,622.35 on July 10th; the value continues to grow. NASDAQ is an exchange for high-tech stocks and can be volatile. These tech companies are not negatively affected by the virus. Instead, their index peaked. This is because there are more online demands. More people are using social media, educational, or occupational meeting apps like Zoom and Facebook. People are also shopping online 
more often, so companies such as Amazon are also benefited. Even after the virus disappears, the virtual way of living will affect the way people daily work and live more or less in a permanent manner.

Graph 14: Stock Prices of Amazon.com Inc (AMZN), Tesla Inc (TSLA), eBay Inc (EBAY), and Netflix Inc (NFLX) in 2020

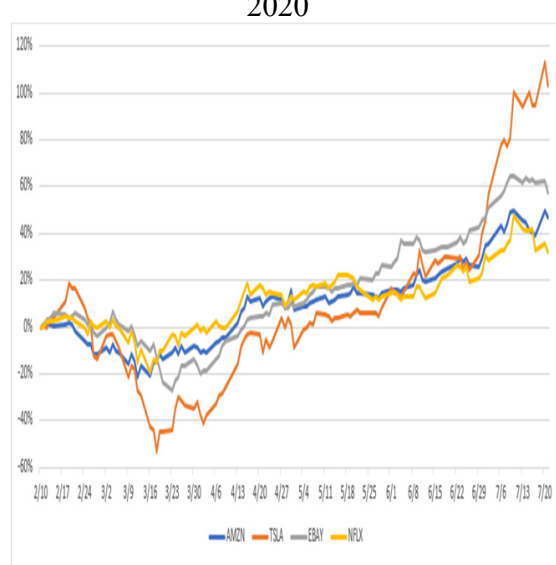

Specification: stock prices for major technology companies, which represent new economic trends, continued increasing despite of COVID-19's impact.

Other than what has already occurred, another reason for the optimism is that the future holds many possibilities for new technology developments. For example, with Space X's reusable launch system development program and the newly introduced Starlinks internet system, there is a positive outlook for aerospace technology. If successful, many more job openings will be available and many yet unknown opportunities for an economic boom will surface. COVID-19 made the government and the people aware of the importance of the healthcare, biotech, and medical industries; many companies are devoting their resources to developing a vaccine. In the future, if a vaccine for the virus or any other disease is developed, the economy would recover and grow significantly. While how long it takes and what the new technology is like have no absolute answers, increases in efforts and companies' dedicated time and resources provide a promising outlook.

Besides new technology, the high consumption propensity the U.S. had before also supports a promising future, though it could be somewhat distant. There are more voices among the people than the government for reopening. So when the number of cases decrease again, retaliatory consumption could very likely occur as people will go out and spend their money traveling, eating, and doing other activities; this would allow economic growth.

In addition to the positive factors stated above, the ability of the U.S. economy to emerge from the crisis as quickly as possible will depend heavily on the impact and promotion of subsequent macroeconomic policies. Following are four policy suggestions. First, the government should not simply inject bulk amounts of liquidity into the financial system; it should instead consider how to direct funds from the financial market to flow into the real economy more efficiently and effectively. For example, encourage banks to grant loans to enterprises and give policy incentives and support to financial institutions through increased loan sizes and interests. At the same time, tax concessions should be granted to enterprises and citizens for loan interest expenses. This would stimulate consumption and investment growth, boosting the economy.

Secondly, it is important to focus on fiscal policies and the scope and intensity of federal investments. For example, there is a large number of infrastructures in the U.S. that have been built over a long period of time but are not fully functional; these infrastructures are usually very costly for maintenance and repair. Thus, the government should increase investment in internal infrastructure improvements. This allows the U.S. to take advantage of this economic crisis to massively upgrade and build new infrastructures, such as airports, railways, electricity, and water resources. On one hand, this can boost investment and employment. And in the long-run, it can lay a solid foundation for future development.

Thirdly, a flexible and adaptable policy response to the variability, complexity, and persistence of the virus is needed. For example, the $\$ 2$ trillion protection policy did work well in the early stages of the epidemic. But relying on such one-time policies is not enough to restimulate the economy enough to step out of the crisis; they may even have made some of the negative effects on the economy as described earlier. Policymakers should consider a more detailed and flexible policy. For example, industry subsidies and support policies should be formulated according to different specific industries. The number of subsidies given to citizens should be determined based on different income and asset levels of citizens. And instead of hoping for a one-time solution, policy adjustments should be introduced at the right time based on the spread of the virus; these adjustments should be tailored to the needs of the population. The policies and their intensity also need to be continuously modified to maximize their effects based on the conditions at the time. For example, there should be more flexibility in subsidies. The government should consider consumer discount vouchers, cash credit vouchers, and other forms of subsidies; the subsidies will lead the economy to have real demand.

Fourthly, in addition to the impact of the epidemic, there have also been some social movements across the U.S. These events should be great concerns for policymakers. The fundamental reason for these unrests is the polarization caused by the disparity between the rich and poor. This is not a problem in the U.S.; it is happening across the world and is extremely complex and difficult to solve. Simple usage of taxes and transfer of payments is not likely to touch on the fundamental core of the problem. This is a systemic undertaking that requires comprehensive economic, political, cultural, and educational reforms and cooperation. The U.S.would have a more solid long-term foundation if it successfully solves the problem of the gap between the rich and the poor properly than if it focuses on economic growth and social stability over the same time period.

In short, while the U.S. economy should be able to recover, the recovery process will take longer than 
2008's due to the many uncertainties. With the total number of cases still increasing and circumstances still unpredictably changing, it could take up to years for full recovery.

\section{Conclusion:}

To conclude, this paper compares and contrasts the 2008 financial crisis with what's happening in 2020 upon the appearance of COVID-19. The primary focuses are the differences in the causes, essence, and government policies between the two crises. While 2008's financial crisis only affected the financial market, COVID-19 has impacted the entire U.S. economy and the people as well. Furthermore, an analysis was conducted on the current policies used and financial market trends, and a prediction for the future and suggestions for changes were given. In 2020, four circuit breakers occurred within ten days and the DJIA value decreased by $38.4 \%$ within one and a half months. But despite this major crash in the stock market, it was able to start recovering after the Fed added liquidity to the market. However, the continuously increasing unemployment rate and low consumption rates show that the actual economy has not recovered yet. Overall, the peak in major technology stocks still sheds a positive light on the situation.

The increasing number of cases after states reopened in an attempt to restore the economy demonstrates the long term and complicated effects of COVID-19. Policymakers cannot just rely on increasing liquidity for the market, but also need to adopt more comprehensive policies such as increasing spending in social security and public investment. In conclusion, even though the long term economic development in the U.S. is optimistic, this crisis, unlike 2008, will take longer and need more complicated processes to recover. Thus, citizens need to be mentally prepared for a long recovery process that will likely affect their lives; policymakers must also be ready to make flexible changes to adjust. Overall, though COVID-19 had severe impacts on the country and made it difficult for the economy to bounce back quickly, there is still a positive prospect long term wise for the country.

\section{References:}

1. https://www.frbatlanta.org/-/me $f$ dia/Documents/cqer /researchcq/gdpnow/RealGDPTrackingSlides.pdf

2. https://www.bea.gov/data/gdp/gross-domestic-produ ct

3. https://www.bea.gov/news/2020/gross-domestic-pro duct-2nd-quarter-2020-advance-estimate-and-annual -update\#: :text=Real\%20gross\%20domestic\%20pro duct $\% 20 \% 28$ GDP $\% 29 \% 20$ decreased $\% 20$ at $\% 20$ an,t he $\% 20$ first $\% 20$ quarter $\% 2$ C $\% 20$ real $\% 20$ GDP\%20de creased $\% 205.0 \% 20$ percent.

4. https://content.schwab.com/web/retail/public/about-s chwab/schw_q2 2020_earnings_release.PDF\#: :text $=$ The $\% 20$ Charles $\% 20 \bar{S}$ chwab $\% \overline{2}$ CCorporation $\% 20$ $\% 28$ NYSE $\% 3 \mathrm{~A} \% 20 \mathrm{SCHW} \% 29 \% 20$ is $\% 20 \mathrm{a}$,in $\% 20 \mathrm{c}$ lient $\% 20$ assets $\% 20$ as $\% 20$ of $\% 20 J u n e \% 2030 \% 2 \mathrm{C} \% 2$ 02020.

5. https://www.bls.gov/web/laus/laumstrk.htm

6. https://data.worldbank.org/indicator/NY.GDP.MKT P.KD.ZG?locations $=\mathrm{DE}$

7. https://data.worldbank.org/indicator/NY.GDP.MKT P.KD.ZG?locations $=\mathrm{BR}$

8. https://data.worldbank.org/indicator/NY.GDP.MKT P.KD.ZG?locations $=\mathrm{MX}$

9. https://data.worldbank.org/indicator/NY.GDP.MKT P.KD.ZG?locations $=\mathrm{IN}$

10. https://data.worldbank.org/indicator/NY.GDP.MKT P.KD.ZG?locations $=\mathrm{GB}$

11. https://data.worldbank.org/indicator/NY.GDP.MKT P.KD.ZG?locations $=J P$

12. https://www.imf.org/external/datamapper/NGDP_R PCH@WEO/OEMDC/ADVEC/WEOWORLD

13. https://www.worldbank.org/en/publication/global-ec onomic-prospects

14. https://data.oecd.org/gdp/real-gdp-long-term-forecas t.htm\#indicator-chart

15. https://content.schwab.com/web/retail/public/about-s chwab/schw_may2020 press release.pdf\#: :text=A bout $\% 20$ Charles $\% 20$ Schwab $\% 20$ The $\% 20$ Charles $\% 2$ 0Schwab\%20Corporation $\% 20 \% 28$ NYSE $\% 3 \mathrm{~A}$,in $\% 2$ 0client $\% 20$ assets $\% 20$ as\%20of $\% 20$ May\%2031\%2C $\% 202020$.

16. https://www.federalreserve.gov/releases/h6/current/

17. https://www.statista.com/statistics/273909/seasonall y-adjusted-monthly-unemployment-rate-in-the-us/

18. https://files.hudexchange.info/resources/documents/ 2019-AHAR-Part-1.pdf

19. https://www.hudexchange.info/resource/5948/2019ahar-part-1-pit-estimates-of-homelessness-in-the-us/

20. https://www.statista.com/statistics/188185/percent-c hance-from-preceding-period-in-real-gdp-in-the-us/\# $: \sim$ text $=$ The $\%$ 20U.S.\%20GDP\%20increased $\% 20$ by $\% 20$ two $\% 20$ percent $\% 20$ from,has $\% 20$ been $\% 20$ mostl y\%20positive $\% 20$ with $\% 20$ some $\% 20$ small $\% 20$ excep tions.

21. https://fred.stlouisfed.org/series/UNEMPLOY

22. https://www.cdc.gov/coronavirus/2019-ncov/cases-u pdates/cases-in-us.html

23. https://www.worldbank.org/en/news/press-release/2 020/06/08/covid-19-to-plunge-global-economy-intoworst-recession-since-world-war-ii

24. https://www.bls.gov/cps/cps_htgm.htm

25. https://fred.stlouisfed.org/series/CSUSHPINSA

26. https://www.cnbc.com/2020/06/21/banks-have-grow n-by-2-trillion-in-deposits-since-coronavirus-first-hit .html

27. https://www.fhfa.gov/SupervisionRegulation/Fannie MaeandFreddieMac/Documents/Freddie_Mac_chart er_Act_N508.pdf 
28. https://www.forbes.com/sites/greatspeculations/2015 /11/16/quantitative-easing-in-focus-the-u-s-experien ce/\#3d7d5760528d

29. https://mitsloan.mit.edu/shared/ods/documents/?Doc umentID $=4598$

30. https://www.congress.gov/bill/116th-congress/house -bill/ $/ 748$

31. https://www.congress.gov/116/bills/hr748/BILLS-11 6 hr748enr.pdf

32. https://home.treasury.gov/policy-issues/cares/assista nce-for-small-businesses

33. http://www.crfb.org/blogs/whats-2-trillion-coronavir us-relief-package

34. https://www.irs.gov/coronavirus/coronavirus-tax-reli ef-filing-and-payment-deadlines 